\title{
Editorial
}

\section{Contributing to Islamic Ethics}

Islamic ethics (akhlaq islamiyah), which is concerned with good character and the means of acquiring it, took shape gradually from the seventh century and culminated in the eleventh century with the teachings of Miskawayh (d. 1030), al-Raghib al-Isfahani (d. 1060), and al-Ghazali (d. 1111). Islamic philosophical ethics combined Qur'anic teachings, the traditions of Muhammad (s), the precedents of Islamic jurists, and classic Greek (Hellenic) ethical ideas.

Prophet Muhammad (s) said: "Verily I have been sent in order to perfect moral character" (Fainnama bu ithtu-li-utamima makarim al-akhlaq). Such prophetic traditions, Qur'anic moral exhortations, and Hellenic ethical writings became the main sources of inspiration for Miskawayh, al-Isfahani, and al-Ghazali. Inspired by the Arabic version of Aristotle's Nicomachean Ethics, these moral philosophers Islamized virtue ethics and focused on cultivating character and purifying the soul (al-nafs). Although al-Isfahani inspired al-Ghazali and tried to maintain a balance between the justice of the soul and the justice of society, the latter developed a Sufi ethics that became increasingly otherworldly with its focus on purifying the self. This ethical model later became a source of inspiration for St. Thomas Aquinas and Maimonides.

This special issue of the American Journal of Islamic Social Sciences focuses on Islamic ethics, especially ethics as applied to such contemporary issues as bioethics, the environment, human rights, and evolution. The papers provide insight into how ethical problems are dealt with within non- 
Islamic contexts, propose ways by which they can be approached in an Islamic context, and analyze some of the differences between the secular and religious approaches to problems of morality. Moreover, while revealing points of continuity with the classical Islamic tradition, they also show the points of change in revised perspectives.

It is hoped that this issue will fill a gap in the teaching of ethics at the university level, where the focus has been either on secular (western) ethics or Christian ethics. Even though Islam is the second largest religion in many parts of the West, there is still a lack of sufficient literature as regards its ethical positions on contemporary ethical problems. These four articles do not cover all of the social issues that require an Islamic ethical response; however, they are the best we have received from the many submissions, given that they are all well-researched and highly relevant to this issue's theme.

When Muslims look for guidance in the area of applied ethics, they turn to religious texts, including the Qur'an, the hadith literature, and Islamic law. While there is no disagreement upon these sources' authenticity, there is also no explicit guidance on how the new dilemmas of our time are to be resolved except through processes of ijtihad (interpretation). Muslims accept the Qur'an as God's word but differ over the interpretation of its verses. For example, God states that we should "not kill a person, for life is considered sacred, except by justice and law" (6:151); but what does this imply in the case of abortion, given that Islam grants human status to the fetus? Interpretations are usually not based on a literal reading of the text, in which case there is ample room for debate and consensus formation on many dilemmas in applied ethics.

Apart from religious sources, Hellenic texts also influenced Islamic philosophical ethics. After al-Ghazali's attack on the "incoherence" of the philosophers, Islamic scholars became more conservative and relied mainly on religious sources because they did not understand that he was condemning the philosophers' metaphysics, which was the ground of their ethics. The distinguished Islamic thinkers and jurists did not depend on religious sources for verdicts only; they also applied reason, in the form of ijtihad. In recent centuries, religious texts have dominated the seminaries' curricula and thereby alienated their graduates from the rich intellectual heritage of Islamic ethics. For the most part, seminaries do not encourage independent analysis and interpretation of the Qur'an. Moreover, the general public tends to submit to religious authorities for fatwas that are based on individual interpretations and thus not binding on Muslim society as a whole. The same 
applies to the authors of these articles. Their interpretations and proposed solutions are not absolute, but they will nevertheless help us make informed decisions about pragmatic issues.

Fast forward to the early modern period, where we are confronted with the impact of classical utilitarianism in the persons of David Hume (d. 1776), Jeremy Bentham (d. 1832), and John Stewart Mill (d. 1873). Classical virtue ethics, whether secular or religious, no longer represented the means to happiness. Utilitarianism focused on utility, pursuing that which causes pleasure and avoiding that which causes pain. It concentrated on providing an empirically grounded rational response to human suffering, not one based on scripture. Bentham considers actions solely in respect of their pleasurable and painful consequences and in terms of their intensity and duration. Thus people will obey those rules that induce pleasure, and right and wrong are meaningful only if they are in accord with the utilitarian principle. Bentham assumes that people will obtain their own greatest happiness by maximizing general happiness.

Mill, agreeing with him, asserted that each person desires pleasure and desires it always in proportion to the magnitude of the pleasure. Unlike Kant, who claimed that moral action should be motivated by duty, Mill held that ethics should be rooted in happiness or pleasure. But unlike Bentham, Mill makes it clear in his Utilitarianism (1861) that there is a clear distinction between the lower pleasures that people share with animals, and the higher pleasures that fall in the realms of the mind and the conscience, such as justice, dignity, love, independence, diversity, self-sacrifice, beauty, and liberty. Perhaps the most important one for him is liberty, as articulated in his celebrated On Liberty (1859). These higher pleasures are not a means to otherworldly happiness. In contrast, Islam considers these higher pleasures as a means to happiness in this world and the Hereafter.

As a social activist engaged in social and educational reform, Mill is not guided by religion. His utilitarian ethics is meant to lead to the general good of society, for its focus is on the right action achieving the aggregate good, not on attaining right virtue. Like most modern philosophers he departed from the Aristotelian model of virtue ethics, whether in its religious or secular form, because he was more concerned with observed action - actions that inspire programs of reform, such as prison reform, free trade, free press, public education, sanitation, and preventative public medicine. Although we take these for granted today, at his time these were new ideas and ideals that promoted individual autonomy, creativity, and selfdevelopment. Even today, utilitarianism remains the key public philosophy 
in our democracies, however complicated it can become with the new problematic of human rights.

Western ethics, as articulated by Hume and Mill, sees benevolence as intrinsic to human nature, albeit that selfishness is a stronger force in human nature. They both espouse the principle of utility, which holds that the greatest happiness for the greatest number should be the guiding principle. Thus happiness should be located within the framework of utility, not human nature. For Mill, the ultimate sanction for morality is not to be found through external punishment; rather, it is to be found through something internal, which he calls the social feelings of humanity. Yet he denies that fellow-feeling is innate in human nature. Thus Mill agreed with Hume that ethics is not a metaphysical mandate, but an offshoot of humanitarian sentiments.

Evolutional ethics rejected the utilitarian criterion for determining good and bad tendencies of actions and replaced it with a more objective biological conception of ethics. It substituted the pleasure principle with the preservation of human society, thereby establishing morality on a scientific basis. Herbert Spencer (d. 1903), a proponent of this view, considered that conduct tending toward the preservation of life is good only on the assumption that life is accompanied by a "surplus of agreeable feelings." This means that actions conducive to preserving life would coincide with agreeable feelings. Social Darwinism is another example of an evolution-based ethics. Many Muslim critics of evolution have linked it with social Darwinism and its implications for racialism, imperialism, and eugenics. They contend that social Darwinism became a pillar of fascist and Nazi ideology. Harun Yahya, a Turkish author, is an example of a Muslim critic who blames Darwinian evolution for Nazism and its crimes against the Jews, the Slavs, and other specific groups. He also holds Darwinian theories responsible for the 9/11 attacks on the United States. In his An Illusion of Harmony: Science and Religion in Islam (New York: 2007, 130), Taner Edis quotes him: "The way to stop acts of terrorism is to put an end to Darwinist-materialist education, to educate young people in accord with a curricula based on true scientific findings and to instill in them the fear of God and the desire to act wisely and scrupulously."

But when divorced from any ideology or empirical application to human beings, biological evolution can be viewed more objectively and need not have any bearing on ethics. This is the view held by David Jalajel, author of Islam and Biological Evolution (Cape Town: 2010). Jalajel, who has contributed the fourth article in this issue, holds that biology and moral- 
ity are two separate domains. Divine legislation pertaining to creation has existential, not moral, value. Moral value can be attributed only to those Qur'anic verses related to human action. Thus biological evolution, which should be placed within the context of divine existential legislation, is morally neutral. He cites the views of classical Sunni scholars in support of his argument. The example of evolution also illustrates for the author the relationship between science and religion, which are based on two different epistemologies.

Muslims today are inspired by traditional Islamic ethics, whether by means of legal, theological, philosophical, or Sufi schools of thought. Their focus has been mainly on either external religious morality or cultivating inner moral character, or both. Less attention has been paid to the social morality that pertains to social justice, human rights, and the attempts to respond in an Islamic pragmatic way to contemporary ethical challenges. Yet we have in the Qur'an and the Islamic ethical legacy a sufficient basis for deriving those ethical principles that can guide us in our response to today's social challenges and dilemmas. With respect to social morality, Islam has much in common with secular ethics, except that the inspiration is derived primarily from revelation. Another difference is that the Qur'anic revelation exhorts us to be just to the self by struggling against its injustices, including such vices as greed and lust. The real challenge is to maintain a good balance. While addressing the injustice of the self we should not neglect the injustice of society, and while addressing the injustice of society we should not neglect the injustice of the self.

Since social justice is an important aspect of human rights, we shall use this concept to show how a classical Muslim scholar developed his own theory of justice, basing it on the Qur'an while taking advantage of contemporaneous knowledge. Al-Raghib al-Isfahani, an open-minded scholar who integrated Aristotelian ethics in an Islamic context, was attracted to Aristotle because he saw the affinity of the latter's ideas with Islam in the recognition of justice as both a moral and a social concept. For a detailed explanation of how he appropriated from Aristotle's theory of justice, see Yasien Mohamed's The Path to Virtue: The Ethical Philosophy of al-Raghib alIsfahani (ISTAC: 2006). The author explains how this scholar integrated foreign knowledge in an Islamic context - Islamic literature, the cultural setting of the period, and the Muslim country in which the foreign knowledge would be applied - and how it became naturalized over time. Al-Isfahani deconstructed classical Greek knowledge and then identified which elements should be integrated. 
Unlike utilitarianism, Islam is concerned not only with public welfare but also with individual morality; not only with material pleasure but also with spiritual pleasure in this world and the next. Islam contains no publicprivate or material-spiritual dichotomies, for all of these concepts are integrated in a schema the origin of which is transcendental. Thus Islam is just as concerned about society's welfare, and so, through the dynamic principle of ijtihad, it is prepared to respond to the new challenges facing the ummah. In addition, the Qur'an both commands the implementation of social virtues (e.g., justice and benevolence) and, crucially, views them as intrinsic to innate human nature (fitrah). Thus there is no need to adopt utilitarianism to be socially relevant, for the principles of social welfare are already contained in Islam. All that remains is to work out the details in accordance with our current knowledge and our reason.

Among the new challenges that we face today and that require an Islamic response are bioethics, human rights, and anthropocentrism. We will comment on each of them in order to set the tone and provide some background for the articles contained in this volume. First, with regard to the challenge of bioethics, we have to distinguish what is good from what is harmful. Questions that need to be answered are: What should we do in the context of certain biomedical circumstances? What are the religious values of the patient and the practitioner? What kind of a society do we seek to construct through our decisions and practices? Secular bioethics is ethically relative and undermines the question of spirituality and religious ethics. Bioethicists generally are not bound by a religious law and so do not make decisions within the framework of revealed texts; Muslim bioethicists, however, have to work within certain limits laid down by the religious law. This does not mean, however, that they cannot contribute to bioethics as a discipline and find solutions that would be helpful to humanity at large. While not denying the medical value of genetic manipulation, for example, they have to be on guard when it comes to certain ethical concerns relating to creating new human types and other issues. To do this, they must apply the processes of reasoning and judgment that are already part of Islamic law and morality.

Human suffering can be due to natural or moral causes. The modern medical approach is concerned only with the alleviation of suffering. But in Islam it is not only a question of cure through medication, for we have to bring God into the picture through such questions as: How does faith in God help a person overcome suffering? How do we reconcile God's justice and kindness with human suffering? How does trust in God help overcome 
incurable illness and suffering due to natural disasters? Thus while Islamic bioethics recognizes the responsibility of the human agent on account of his/her free will, he/she is still bound by a belief in God's omnipotence, which can help a great deal in cultivating patience as a way of coping with unbearable pain and the inevitable loss of a dear one. Indeed, we need to examine the Islamic concept of human obligation toward those who suffer; but to do so we need healthcare practitioners to cooperate with traditional Islamic scholars.

To solve human problems is not just a matter of alleviating pain and inducing pleasure; it is also a matter of doing this in accordance with our conscience and for the sake of earning God's pleasure. Our own happiness depends on this. As mentioned, Islam encourages the virtues of benevolence and justice. In the context of bioethics, benevolence implies taking care of patients and justice implies the fair distribution of scarce resources to meet their needs. The secular biomedical approach is not always compatible with Islam's ethical values. When it comes to death, disease, and suffering, we cannot adopt a strictly utilitarian approach because our treatment of these problems should be logically consistent with the Islamic metaphysical framework.

Another challenge to Islamic ethics is that of human rights, a topic discussed by Marie-Luisa Frick in her "Ummah Rights or Human Rights? Universalism, Individualism, and Islamic Ethics in the Twenty-first Century," which examines the potential of Islamic ethics to revitalize human rights. The central thrust of the Islamic tradition has been on human duties - duties to God and to humanity - not on human rights. The secular notion of human rights emerged within the context of secular modernity. The secular government represents the people and their various rights, including the rights to abortion, suicide, and sexual orientation. Islam's focus has been on human obligations, and through these obligations the rights of others are fulfilled, including any rights attributed to the fetus. Since Islam does not provide the Muslim with absolute freedom, his/her rights have been constrained. So, for example, a human being cannot have the right to commit suicide. In this sense, Islam comes into direct conflict with secular democracy. Nevertheless, the question that should be asked is whether Islam should develop a culture of human rights from the Islamic perspective.

A good starting point for an Islamic perspective on human rights is to analyze the Qur'an's main principles. The Qur'an makes it clear that God has created humanity equally "from a single pair of male and female" (49:13) and that He has honored man by making him "God's vicegerent on 
Earth" (2:30). (It should be noted here that when the Qur'an uses the masculine gender, it is inclusive of women). Thus when it comes to the principle of equality, the Islamic concept of humanity is not very different from the secular concept. However, when it comes to how this concept is actualized in a social context, there are differences, for example, on the questions of polygamy and inheritance. Under certain conditions, a Muslim man is permitted to have more than one wife and, with regard to inheritance, receive a larger share than a woman. There is no space here to explain the reasons given for this, but Frick's article raises important questions, such as whether Islam can demonstrate that it has its own version of human rights and therefore does not have to conform to the western liberal tradition, and whether individual rights in Islam can be balanced with social rights, including the rights of non-Muslims in an Islamic state.

If human equality is present in Islam, then why does the Qur'an mention that men are women's protectors and that those who have knowledge are superior to those who do not? God's unity, as a metaphysical principle, does imply humanity's unity. Although the Qur'an makes social distinctions between men and women, this does not imply a man's ontological superiority over a woman. Rather, it is only a differentiation in their social roles. This does not accord well with secular human rights, which acknowledge the innate equality of men and women but does not trace its source to God. For Muslims, innate human equality is endowed by God.

Secular humanism places great emphasis on freedom of thought and expression. Free press, peaceful public protest, freedom of religion, and the right to assemble all stem from this central idea of freedom. In the Muslim world, such freedoms stem from other sources of guidance, not only from reason. This idea is expressed most powerfully in Mill's On Liberty, a treatise on civil liberty that deals with the extent of society's power over an individual's liberty. He explains that his predecessors had to fight the tyranny of despotism, but that now there is a need to fight the tyranny of the majority. Alexis De Tocqueville's Democracy in America (1945) echoes this idea when he discusses the tyranny of the majority, which tends to impose itself on the individual.

Mill rejects this tyranny on the grounds that there should be limits to such an imposition. There are parallels to this position in Islam, as it recognizes the individual's liberty. But there are limits to this liberty, imposed not by a secular state but by the revealed law. Islam presents freedom as a trust from God, and thus as something that cannot be abused according to one's whim. No person has the right to commit suicide, for only God can take life. 
A mother has no right to an abortion, especially after four months when the fetus is accorded human status because of ensoulment. There are, of course, exceptions to this rule. Secular worldviews find such constraints unacceptable. And yet the secular mind does not find it unacceptable that the majority population in a secular democracy imposes its will upon the liberty of the individual. To be sure, freedom is central to being human, whether in a secular democracy or in Islam. But in Islam, human beings are ultimately accountable to God for how they use their freedom.

Frick holds the view that although secular human rights have been criticized for absolute notions of individual rights and individual autonomy, it is common sense for most people to acknowledge that individual freedom has its limits and should be balanced with the needs of society. Indeed, Islam does impose limits on the individual's freedom, but only with the intention of liberating people from slavery to their lower self (nafs), whether it is expressed in the form of pride, greed, or lust. Frick cites examples of Islamic scholars who stated that all governments have to impose laws to maintain order in society. As for rights in Islam, she cites the right of men and women to own property as but one example.

As mentioned, justice, equality, dignity, and other secular concepts are also found in Islamic religious sources. In the Islamic context they have both a social and ethical importance as well as, significantly, a religious value. These concepts shape Muslim piety as they spring from revealed sources and, because of their religious origin, have a far greater power to inspire social change than any secular philosophy. This is not only because of the religious idiom's power, but also because the divine origin inherently constructs community as opposed to a mere aggregate of individuals. For example, the Qur'an states: "Justice is nearer to piety" (5:8), which means that justice is associated with spirituality. The Prophet stated: "All newborn human beings are born with the pure innate nature (fitrah)," meaning that everyone is born with equal dignity and thus should be accorded equal treatment. The Qur'an also recognizes variation among individuals. For instance, those who fight in God's cause are superior in rank to those who do not (57:10). Thus all people are equal, but some are treated more unequally than others, depending upon their effort.

In other words Islam creates a hierarchy, but a hierarchy based on piety rather than economics or power. Thus there is no dispute about the clear Islamic principles in the primary Islamic sources, even though there are differences on how we use our reason and the extent to which we embrace current knowledge. According to Jürgen Habermas, the western secular view of 
human dignity has its roots in the Biblical statement: "Man is made in the image of God" (Genesis 1:27). This means that scripture can be a source of respect for human dignity and perhaps have a more powerful impact on religious people than the secular text would have on secular people. Likewise, the Qur'an can also be a source of guidance and inspiration for contemporary Muslims to live with a sense of justice and respect for human dignity in a secular democracy that espouses these very values.

As discussed, for classical scholars such as al-Isfahani, the principle of justice is enshrined in the Qur'an and the details of its application in society can be worked out through human reason. Contemporary Islamic scholars such as Hashim Kamali and Yusuf al-Qardawi hold the same view, stressing the need for ijtihad in working out the details of justice. This ijtihad is commendable, even if the outcome is incorrect. Thus one should not be afraid of making an error in his/her ruling, as it is only binding on the community if it gains the consensus of Muslim jurists (ijma'). Thus the details of justice can be sought outside the revealed law, provided that the routes to it are in keeping with the Qur'an's overriding principles.

In this issue, Hamid Mavani's "Ijtihad in Contemporary Shi' ism" deals with the role of reason in solving contemporary problems. He analyzes the integral relation between ijtihad and ethics, as well as on the need for ijtihad to fulfill the religious law's intentions (maqasid). While past ijtihad dealt mainly with matters of worship and religious issues affecting the individual, today we need to apply it to matters affecting society as a whole. Moreover, we need to meet the demands of Muslim states and address the global challenges of consumerism, secularism, environmentalism, bioethics, and pluralism. Mavani is concerned that the Shi ah are receiving incorrect ideas about salvation, which they perceive to be divorced from ethics. They need to know that the social welfare of society is just as important as the spiritual welfare of the individual.

Muslim scholars also need to address the challenge of anthropocentricism, the critique of which has been at the heart of environmental ethics. The radical environmentalist critique, despite its power, does not come up with viable alternatives. Islamic environmental ethics does provide an alternative, but first has to rebut anthropocentricism from an Islamic perspective. Ali M. Rizvi states, in his "Islamic Environmental Ethics and the Challenge of Anthropocentricism," that Islam rejects anthropocentrism because it does not acknowledge the concept of a transcendent God Who is unlike His creation. But because of the One Creator we are related to every other aspect of 
creation, including plants, animals, and minerals, and so tend to respect nature instead of treating it as something exploitable. We should not embrace the "use value," for the value of all things in relation to God is limitless and thus cannot be exhausted, as they manifest (in essence) God's wisdom. Kantian enlightenment morality reduces God to a partner, refusing to see God as the divine power Who determines all things. This robs the human being of Islam's very essence: one's servitude to God. Kant's anthropocentric view of morality is therefore problematic. In Islam, the human will has to conform to the divine will; since God grants human will as a trust, God cannot be an equal partner to humanity. Islam seeks to avoid anthropocentricism, which consists in making human desires and their fulfillment the center of social and ethical life.

But Adam Smith (d. 1790), for example, holds in An Enquiry into the Nature and Causes of the Wealth of Nations that the social welfare of society is dependent upon the individual's self-interest and that an "invisible hand" causes society as a whole to benefit. People cooperate with others for the sake of individual welfare, not for the welfare of others. The "invisible hand" is not a divine hand, but rather a natural force that guides free market capitalism, where each participant tries to maximize his/her own selfinterest, which, through a division of labor, benefits the whole society. Smith states in his Wealth of Nations: "It is not from the benevolence of the butcher, the brewer or the baker, that we expect our dinner, but from their regard to their own interest." In Islam, expressing benevolence through charity is natural to the human being's innate nature of goodness; therefore, the good done for society is not something accidental, but intentional.

Utilitarianism focuses on society's material, as opposed to spiritual, welfare. Ibn Khaldun (d. 1406) opined that Islam does not negate the need for material goods, provided that one acknowledges that all sustenance comes from God. The pursuit of wealth for its own sake, merely for material comfort and ego, is not permitted. He understood the need for profit as the only incentive for trade and for motivating artisans to pursue their crafts, as well as the fact that wealth was abundant in the cities, the crafts flourished as people were prepared to pay for one's labor and skill. Fully aware of the human propensity to improve their material standards of living, he cautioned against the immoderate use of wealth for the purpose of luxurious living and its adverse effect upon human morality. Even more than al-Ghazali, he encouraged people to work hard, develop their talents, and build a civilization; but also warned them against excessive luxury and explained how it could lead to sloth and immorality. 
Islam denies the tyranny, but not the legitimate fulfillment, of desire. Islamic ethics is intimately connected to spirituality and to emulating the prophets and saints. Religious practices, such as fasting and praying, encourage frugality, for waste and the excessive satisfaction of even legitimate desires can result in the lower self dominating the individual and the institutionalization of excess in the economy, which could ultimately lead to imbalance and chaos. Islamic ethics rejects desire-based morality in favor of a morality based on a metaphysics that rejects the eternity of the present world, for only this type of metaphysics can curb consumerism's dominance. We can still be prosperous if we subordinate our desire to God's will, but not at the expense of our faith and nature's destruction. Rizvi proposes an ethical-religious framework that can sustain a justifiable use of nature and its resources without exploiting them. His paper ends by considering possible objections and challenges to developing a philosophically viable, yet religiously oriented, environmental ethics.

The main principles of secular ethics, such as justice, benevolence, and free will, are also present in Islamic ethics and have always been operative in Muslim societies; however, the context in which they function differs. We need to reinterpret these Qur'anic principles, and reinterpret them for our new context. The Qur'an also recognizes human autonomy, but this autonomy requires that we act as the vicegerents of God, meaning that we act like stewards in guiding humanity toward happiness in this world and the Hereafter. Justice, whether driven by benevolence or selfishness, is an important principle of modern western ethics. But Islam links justice to piety, and the challenge still remains as to how we can apply it to our practical situations. Whether we are dealing with bioethics or environmental issues, it is important that Muslim scholars engage with the social sciences and develop a multidisciplinary scholarship in order to find solutions to our dilemmas.

Islam can make a positive contribution to the social concerns of biomedical and environmental issues not only because of its faith and the contents of its intellectual legacy, but also because of its powerful methods of communicating moral truths through stories, metaphors, and the Prophet's (s) concrete example. Islamic morality's content, as well as the historical context in which it has played a positive role, can inspire Muslims to act with justice and benevolence. It is up to contemporary Islamic thinkers to extract Islam's cognitive moral content and rearticulate it in a way that is intelligible to modern people so they can derive inspiration and guidelines. There is no reason why non-Muslims should not find its cognitive moral content appealing and, by means of either identifying with the Islamic worldview or 
with the power that it has on Muslims, work toward practical solutions that will benefit everyone. For Muslims, it would have an intrinsic value because of the inspiration from sacred sources and also an extrinsic value because of its utility and benefit to all. Thus there is no need for them to turn to a secular philosophy for extrinsic benefit.

Utilitarianism, which is partly inspired by secular philosophies of human nature and ethics and promotes the pleasure principle as the key to the happiness of the majority, has gripped contemporary humanity. Secular democracies, due to their capitalist-based economies, have been particularly receptive to it. The result of secular capitalism, an outgrowth of the Enlightenment's labor theory of value and division of labor, is that material acquisition and physical comfort have become the yardstick for what is good. Given this reality, we accord little or no value to moral character and spirituality. Within the framework of these economies, we worship our own desires and egos and eventually become engrossed in consumerism and wealth accumulation. The result is that we sacrifice our principles, whether humanitarian or religious, at the altar of self-indulgence and acquisitiveness.

Islamic ethics could help Muslims become better persons and better citizens. It could also help non-Muslims, who could benefit both from the practical solutions of the Muslim contribution and from the moral example of Muslims. This issue adds to the existing literature in the field of contemporary Islamic ethics. This is only the beginning. More can be done if Muslim scholars, both with a traditional Islamic grounding and with a social scientific background, can work together to solve contemporary problems. We cannot bury our heads in the sand and believe that all is well around us because "God is on our side." We have to apply our minds to the challenges of our own time, not in order to change Islam but rather to find Islamic solutions to new problems in the area of social relations. This is what ijtihad is all about, and we already have an example in al-Isfahani of how an Islamic theory of justice was formulated on Qur'anic principles and contemporaneous knowledge.

Muslim theologians, jurists, and healthcare workers have been addressing the challenges of modern biotechnology, environmentalism, and human rights, but so much more remains to be done. The four articles contained in this issue cover some of these aspects. Although not comprehensive in dealing with all ethical problems, they provide us with some good insights and proposed solutions from an Islamic perspective, which could benefit both Muslim and non-Muslims. 
In this introduction we have attempted to place Islamic ethics in a historical perspective and identify the challenges facing contemporary Muslims. We have emphasized the need to rearticulate the main principles of human dignity, human equality, and human justice in Islam for our contemporary social context. We present these articles as an addition to contemporary Islamic ethical literature. This is the promise and hope of Islamic ethics in the twenty-first century.

Yasien Mohamed

Special Issue Guest Editor Professor of Arabic Language and Islamic Philosophy Department of Foreign Languages University of the Western Cape, South Africa

Norman K. Swazo Special Issue Guest Editor Professor of Philosophy and Biomedical Ethics College of Science and General Studies Alfaisal University, Saudi Arabia 